\title{
Microbial Barrier Property \\ and Blood Compatibility Studies \\ of Electrospun Poly- $\varepsilon$-Caprolactone/ \\ Zinc Oxide Nanocomposite Scaffolds
}

\author{
Robin Augustine ${ }^{* a, d}$, \\ Nandakumar Kalarikkal ${ }^{\mathrm{a}, \mathrm{b}}$ and Sabu Thomas ${ }^{* a, \mathrm{c}}$ \\ ${ }^{a}$ International and Inter University Centre \\ for Nanoscience and Nanotechnology \\ Mahatma Gandhi University \\ Kottayam 686 560, Kerala, India \\ ${ }^{b}$ School of Pure and Applied Physics \\ Mahatma Gandhi University \\ Kottayam 686 560, Kerala, India \\ 'School of Chemical Sciences \\ Mahatma Gandhi University \\ Kottayam 686 560, Kerala, India \\ ${ }^{d}$ School of Nano Science and Technology \\ National Institute of Technology Calicut \\ Kozhikode, Calicut 673 601, Kerala, India
}

Received 27.02.2017, received in revised form 11.05.2017, accepted 12.05.2017

Electrospun poly- - -caprolactone/zinc oxide $(\mathrm{PCL} / \mathrm{ZnO})$ nanocomposite scaffolds were reported for tissue engineering and wound healing applications. Wound coverage materials should have good barrier property against invading microbes. Since wound coverage materials and tissue engineering scaffolds are in direct contact with blood, such materials should be blood compatible. Thus, blood compatibility of the fabricated scaffolds has been tested by RBC and WBC aggregation studies. Hemolysis assay and platelet activation study were also carried out. This study is promising in the sense that the fabricated scaffolds showed excellent microbial barrier property and were highly compatible with RBC and WBC and did not induce haemolysis. However, need to be vigilant regarding the possible platelet aggregation that can happen at higher concentrations of $\mathrm{ZnO}$ nanoparticles.

Keywords: poly- $\varepsilon^{-c a p r o l a c t o n e, ~ z i n c ~ o x i d e, ~ t i s s u e ~ e n g i n e e r i n g, ~ s c a f f o l d s, ~ b l o o d ~ c o m p a t i b i l i t y, ~}$ microbial barrier property.

(C) Siberian Federal University. All rights reserved

* Corresponding author E-mail address: robin@robinlab.in, sabuchathukulam@yahoo.co.uk 

poly- $\varepsilon$-caprolactone/zinc oxide nanocomposite scaffolds. J. Sib. Fed. Univ. Biol., 2017, 10(2), 226-236. DOI: 10.17516/19971389-0025.

\title{
Исследование противомикробных барьерных свойств и совместимости с кровью полученных \\ электропрядением нанокомпозитных скаффолдов поли-ट-капролактон/оксид цинка
}

\author{
Р. Аугустин ${ }^{\mathrm{a}, \mathrm{r}}$, Н. Калариккал ${ }^{\mathrm{a}, \boldsymbol{\sigma}}$, С. Томас ${ }^{\mathrm{a}, \mathrm{B}}$ \\ ${ }^{a}$ Международный и наииональный университетский центр \\ в области нанонауки и нанотехнологии \\ Университет им. Махатмы Ганди \\ Индия, 686 560, штат Керала, Коттаям, \\ ${ }^{6}$ Институт фундаментальной и прикладной физики \\ Университет им. Махатмы Ганди \\ Индия, 686 560, штат Керала, Коттаям \\ ${ }^{6}$ Институт химических наук \\ Университет им. Махатмы Ганди \\ Индия, 686 560, штат Керала, Коттаям \\ 'Институт нанонауки и технологии \\ Национальный институт технологии Каликут \\ Индия, 673601, штат Керала, Каликут, Кожикоде
}

\footnotetext{
Изучены полученные электропрядением нанокомпозитные скаффолды поли-г-капролактон/ оксид ичинка (PCL/ZnO), которые могут быть использованы в тканевой инженерии и при лечении ран. Материалы раневых покрытий должны иметь высокие противомикробные барьерные свойства. Поскольку материалы раневых покрытий и тканеинженерные скаффолды находятся в прямом контакте с кровью, такие материалы должны быть кровесовместимыми. Поэтому была исследована совместимость полученных скаффолдов с кровью путем оценки агрегаџии эритроцитов и лейкоциитов. Также была проведена гемолизная проба и исследование активации тромбоцитов. Исследование показало хорочие противомикробные барьерные свойства и высокую совместимость скаффолдов с эритроцитами и лейкоцитами, а также отсутствие индукиии гемолиза. Однако при высоких концентрациях наночастии ZnO может отмечаться агрегаиия тромбоцитов.
}

Ключевые слова: поли-г-капролактон, оксид ицика, тканевая инженерия, скаффолды, кровесовместимость, противомикробные барьерные свойства. 


\section{Introduction}

Electrospinning technology, which can easily mass-produce thin nano to submicron fibrous membranes with good conformability, could offer a solution to fabricate tissue engineering scaffolds and skin substitutes (Recek et al., 2016). Electrospun nanofibers resemble the native topographical features of the natural extracellular matrix and may promote natural functions of the cell in a biomimetic fashion. Electrospun membranes have various properties that make them suitable as skin substitute materials such as high oxygen permeability, variable pore size, a high surface area to volume ratio and morphological similarity to the extracellular matrix (ECM) (Smith et al., 2004; Zahedi et al., 2010). Various natural and synthetic polymers/ polymer blends have been electrospun into nanofibers to generate potential wound dressing materials. The ability to incorporate a variety of bioactive molecules (such as antimicrobials, anti-inflammatory agents) into the nanofibers can increase the desirable wound healing (and wound dressing) properties (Augustine et al., 2016b).

Recently, poly ( $\varepsilon$-caprolactone) (PCL) has drawn a lot of attention in biomedical applications (Nandagopal et al., 2016). PCL has several advantages including low cost, biocompatibility, and biodegradability (Eldsäter et al., 2000). PCL has been suggested in applications such as drug delivery system (Zhong et al., 2001; Allen et al., 2000), tissue-engineered skin (plain film) and scaffolds for supporting fibroblasts and osteoblasts growth (Hutmacher et al., 2001), etc.

Electrospun PCL scaffolds containing various metal oxide nanoparticles were fabricated and extensively studied for the physicochemical properties and cytocompatibility both in vitro and in vivo (Augustine et al., 2017b; Augustine et al., 2017c). As the concentration of $\mathrm{ZnO}$ nanoparticles has increased, both fiber diameter and fiber morphology were varied greatly (Augustine et al., 2014c). ZnO nanoparticles incorporated scaffolds have shown superior mechanical properties than the neat PCL ones. Then, these nanocomposite membranes have been evaluated for the antibacterial property, cell proliferation, cytocompatibility and the in vitro degradation. Incorporation of $\mathrm{ZnO}$ nanoparticles in electrospun PCL membranes imparted antibacterial property to the scaffolds (Augustine et al., 2014c). The fabricated PCL/ZnO nanocomposite membranes have shown enhanced biodegradation than the neat PCL membranes (Augustine et al., 2016a). Presence of $\mathrm{ZnO}$ nanoparticles promoted wound healing by enhanced angiogenesis, cell adhesion, migration and proliferation (Augustine et al., 2014a, b).

In addition to the detailed antibacterial, cytocompatibility and wound healing studies, it is essential to understand the ability of PCL/ZnO nanocomposite scaffolds to prevent the entry of microbes to the wound. Thus, the microbial barrier properties of $\mathrm{PCL} / \mathrm{ZnO}$ nanocomposite scaffolds was evaluated in the present study. Moreover, the blood cell aggregation and hemolysis due to PCL/ $\mathrm{ZnO}$ scaffolds is very important to be explored. Hence, the aggregation behavior of human blood cells due to the effect of PCL/ZnO nanocomposite scaffolds was addressed in this study. Hemolysis due to these scaffolds were also evaluated.

\section{Materials and methods}

\section{Fabrication of scaffolds}

Electrospun $\mathrm{PCL} / \mathrm{ZnO}$ nanocomposite scaffolds were fabricated by our reported procedure (Augustine et al., 2014c). PCL scaffolds containing $0.5 \% \mathrm{w} / \mathrm{w} \mathrm{ZnO}$ nanoparticles, $1 \% \mathrm{w} / \mathrm{w}$ $\mathrm{ZnO}$ nanoparticles, $2 \% \mathrm{w} / \mathrm{w} \mathrm{ZnO}$ nanoparticles, $4 \% \mathrm{w} / \mathrm{w} \mathrm{ZnO}$ nanoparticles and $6 \% \mathrm{w} / \mathrm{w} \mathrm{ZnO}$ nanoparticles were fabricated and denoted by the codes PCL/ZnO-0.5, PCL/ZnO-1, PCL/ZnO-2, $\mathrm{PCL} / \mathrm{ZnO}-4$, and PCL/ZnO-6, respectively. The scaffolds were characterized for morphology by 
JEOL JSM 6390 scanning electron microscopy. A Philips XL-30 FEG Scanning Electron Microscope was used to analyze electrospun PCL samples at higher resolution to visualize $\mathrm{ZnO}$ nanoparticles in the fibers. PCL and $\mathrm{ZnO}$ (about $60 \mathrm{~nm}$ ) nanoparticles used in this study were purchased from Sigma Aldrich, India.

\section{Determination of microbial barrier} property $(M B P)$

To measure the Microbial Barrier Property (MBP) of electrospun PCL/ZnO nanocomposite scaffolds, our previously reported procedure was used (Augustine et al., 2015). Sample bottles with $2 \mathrm{~cm}$ mouth diameter was used for this study. A hole with the diameter of $2 \mathrm{~cm}$ were made on the caps of the bottle. The bottles and their caps were sterilized by autoclaving at $121{ }^{\circ} \mathrm{C}$ and $15 \mathrm{lbs}$ pressure for 15 minutes. All the membranes were dipped in $70 \%$ alcohol and UV irradiated for 15 minutes. Sterilized media (Peptone water, Himedia, India) was poured into the bottle and placed in a laminar air flow system to get cooled. After cooled to room temperature, the holes on the caps were covered with the samples (neat PCL and PCL/ZnO nanocomposite scaffolds). A positive control was also maintained which was a standard wound coverage material (Cipla FirstAid, Cipla, India). Then, the bottle-membrane assemblies were kept in an open hall with a relative humidity of $70 \%$ and a temperature of $28{ }^{\circ} \mathrm{C}$. After 24 hours of incubation, the bottle-membrane assemblies were placed in laminar air flow system. After removing cap and the membrane, 100 microliter of the peptone water from the bottles were poured on the centre of Mueller Hinton agar (Himedia, India) plates and spread plated in triplicates. The plates were incubated for overnight. Colony Forming Units (CFUs) were counted and the Microbial Barrier Property (MBP) was measured using the equation (1).
$\operatorname{MBP}(\%)=\frac{(\text { Positive control }- \text { Test sample }) \times 100}{\text { Positive control }}$.

All the experiments were carried out in triplicates and expressed as mean $\pm \mathrm{SD}$.

\section{Blood compatibility studies}

There are two important tests which are used to evaluate the blood compatibility of materials, blood cell aggregation and hemolysis tests. Both blood aggregation study and hemolysis assay were carried out according to the reported protocol (Augustine et al., 2017a). Human blood sample was collected from healthy volunteers in a tube containing $3.8 \%$ sodium citrate at 9:1 ratio (blood : anticoagulant). The collected blood was used for both aggregation and hemolysis studies. Electrospun membranes of neat PCL and those containing various amount of $\mathrm{ZnO}$ nanoparticles were used for blood compatibility studies. Normal saline and Polyethylenimine (PEI, Alfa Aesar, USA) were used as the negative and positive controls, respectively. Both neat PCL and PCL/ZnO nanocomposite membranes were cut into $1 \times 1 \mathrm{~cm}^{2}$ size and sterilized by dipping in $70 \%$ alcohol for 20 minutes and UV irradiation for 20 minutes. The samples were then kept for overnight incubation in $1 \mathrm{~mL}$ PBS (Life Technologies, India) solution and these solutions were used for hemolysis assay, RBC aggregation, WBC aggregation and platelet activation.

\section{Blood cell aggregation study}

To perform RBC aggregation studies, the blood was centrifuged at $700 \mathrm{rpm}$ for $10 \mathrm{~min}$ to separate the RBC from the blood plasma. This separated layer was washed twice with saline and diluted with PBS (1:4). $2 \mathrm{~mL}$ of this diluted $\mathrm{RBC}$ was added to the PBS solution in which the membranes were kept previously for overnight incubation, and then kept at $37^{\circ} \mathrm{C}$ for 20 minutes. The diluted $\mathrm{RBC}$ was also incubated along with negative and positive control. 
The WBC compatibility study was done with anti-coagulated blood $(1 \mathrm{~mL})$ overlaid with histopaque (1 mL, Sigma Aldrich, India) in order to make two separate layers and was centrifuged for 15 minutes at $800 \mathrm{rpm}$ at room temperature. $\mathrm{RBC}$ goes to the bottom of the tube, histopaque come at the middle and WBC above the histopaque layer. The top layer will be the platelet layer. The collected WBC was incubated with PBS solution in which the membranes were kept previously for overnight incubation, for 20 minutes at $37^{\circ} \mathrm{C}$. Similar procedure was carried out for the incubation of $\mathrm{WBC}$ with the positive (PEI) and negative (Normal saline) controls.

After incubation, both the cells were isolated by centrifugation, resuspended in PBS and examined on wet mounted slides and the images were captured by phase contrast microscope (Leica DMIRB).

\section{Platelet activation}

Platelets were isolated from anti-coagulated blood $(1 \mathrm{~mL})$ overlaid with histopaque $(1 \mathrm{~mL})$ in order to separate blood cells as separate layers and was centrifuged for 15 minutes at $800 \mathrm{rpm}$ at room temperature. The platelets were separated as the topmost layer above WBC layer. The collected platelets were incubated with PBS solution in which the membranes were kept previously for overnight incubation, for 20 minutes at $37{ }^{\circ} \mathrm{C}$. Similar procedure was carried out for the incubation of platelets with the positive (PEI) and negative controls (Normal saline).

\section{Hemolysis assay}

Hemolysis assay was carried out on PCL membranes and PCL membranes containing various concentrations of $\mathrm{ZnO}$ nanoparticles. In brief, $100 \mu \mathrm{l}$ of the separated blood was diluted with $800 \mu \mathrm{l}$ saline. To this diluted blood, $100 \mu \mathrm{l}$ of each PBS solution in which the membranes were kept previously for overnight incubation, was added. Here, normal saline was used as negative control and distilled water as positive control. The samples were incubated for 30 minutes at $37{ }^{\circ} \mathrm{C}$ and were centrifuged at $700 \mathrm{rpm}$ for $5 \mathrm{~min}$. The optical density (OD) was measured at $541 \mathrm{~nm}$ using a UV-Vis spectrophotometer (Shimadzu doublebeam spectrophotometer-Model 1700). Percentage of hemolysis was calculated from equation (2).

$\%$ Hemolysis $=\frac{[O D \text { of sample }- \text { OD of }- \text { ve control }]}{[O D \text { of }+ \text { ve control }- \text { OD of }- \text { ve control }]}$.

\section{Results and discussion}

Fiber morphology

Presence of $\mathrm{ZnO}$ nanoparticles of various concentration ranges from $0.5 \% \mathrm{w} / \mathrm{w}$ to $6 \% \mathrm{w} / \mathrm{w}$ in PCL fibers, significantly changed the fiber morphology provided other experimental parameters remained constant. Fig. 1A shows the SEM image of neat PCL membrane. From the figure it is clear that the surface of individual fibers are smooth. It can be observed from the SEM micrographs that both PCL and PCL/ZnO nanocomposite membranes were highly porous in morphology. Pore spacing measurement from SEM micrographs has shown that all the fabricated membranes had an average pore spacing of $11.4 \pm 3.2 \mu \mathrm{m}$. Fig. 1B shows the SEM micrographs of $\mathrm{PCL} / \mathrm{ZnO}$ nanocomposite membranes containing $1 \% \mathrm{w} / \mathrm{w}$ of $\mathrm{ZnO}$ nanoparticles. Here, fiber morphology was almost uniform with micro and nanofibrous structures. Fig. $1 \mathrm{C}$ shows the presence of well dispersed $\mathrm{ZnO}$ nanoparticles on individual fibers. There were no agglomerations of $\mathrm{ZnO}$ nanoparticles at this nanoparticle concentration. Fig. 1D shows the formation large agglomerations of $\mathrm{ZnO}$ nanoparticles on PCL fibers with $4 \% \mathrm{w} / \mathrm{w} \mathrm{ZnO}$ nanoparticle content. High surface energy of nanoparticles causes them to agglomerate together and this tendency is high at higher concentrations of nanoparticles (Wang et al., 2002). 

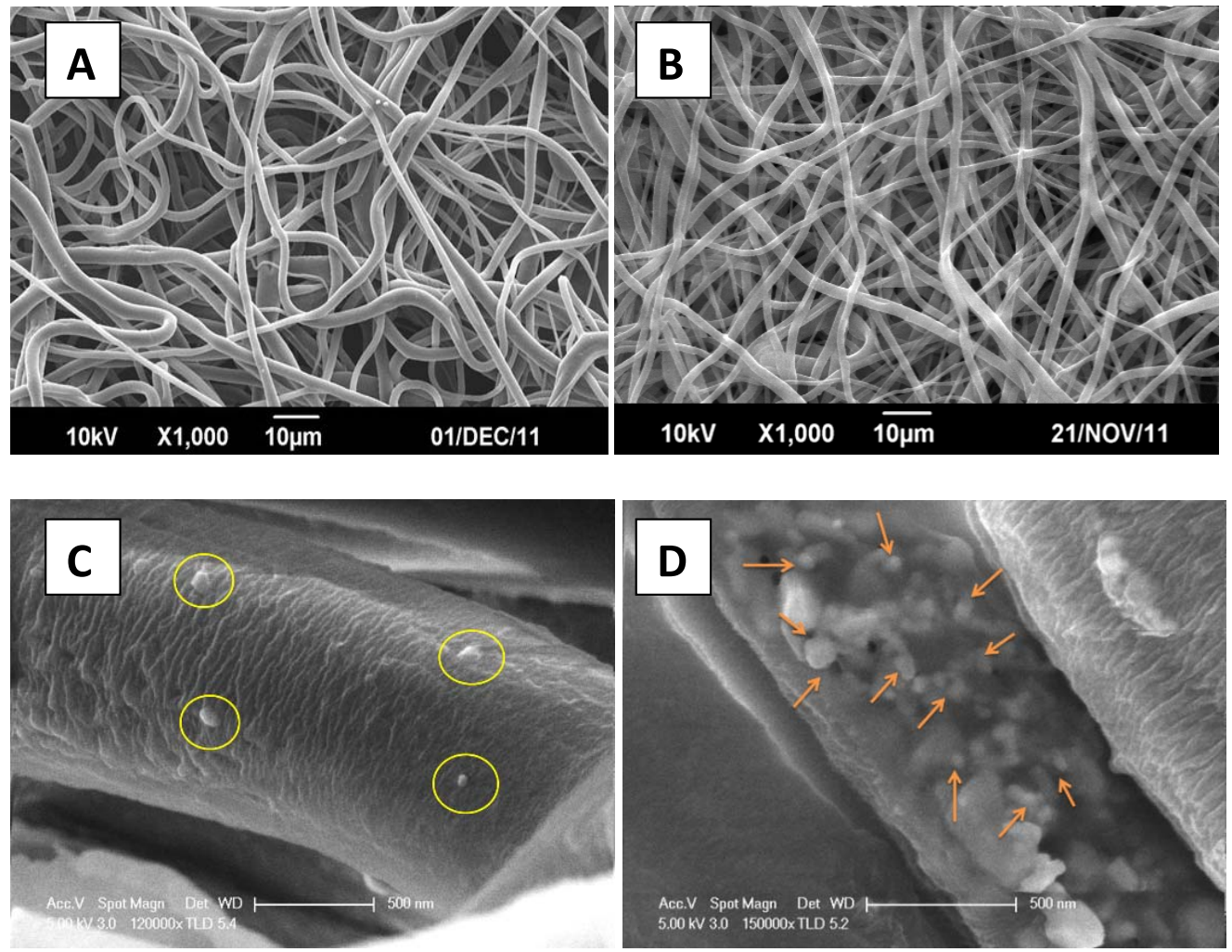

Fig. 1. Scanning Electron Micrograph of electrospun neat PCL scaffold (A) and PCL scaffolds with $1 \% \mathrm{w} / \mathrm{w} \mathrm{ZnO}$ nanoparticles (B). (C) and (D) are the high resolution SEM images of PCL scaffolds containing $1 \%$ and $4 \% \mathrm{w} / \mathrm{w}$ $\mathrm{ZnO}$ nanoparticles respectively

\section{Microbial Barrier Property (MBP)}

Microbial Barrier Property (MBP) was calculated from the Mueller Hinton Agar (MHA) plates which was spread plated with the peptone media from the sample bottles covered with the membranes as well as the negative control without any coverage. Microbes penetrated through the membranes into the media were multiplied there and these bacteria could produce colony forming units in the MHA plates. Here, the MBP is expressed as the ability of the membrane to prevent the microbial invasion in percentage compared to a control. The positive control can be any standard dressing material or bandage which is commonly used for the applications similar to the application of the newly developed material. Resulting MBP with reference to positive control is given in Table 1. Here, Cipla 1st AID has taken as the positive control. While calculating the MBP with reference to positive control, neat PCL membrane had shown to have $95 \%$ MBP. Since the pore size is the major factor that affect the MBP, PCL/ZnO nanocomposite membranes have also shown comparable MBP (with an average MBP of $95.6 \pm 0.89 \%$ ).

The evaluation of microbial barrier property of PCL/ZnO nanocomposite scaffolds showed that all the scaffolds showed very high bacterial barrier property irrespective of $\mathrm{ZnO}$ nanoparticle content. Thus, these scaffolds can be used as potential skin substitutes for preventing the entry of the microorganisms to wounds.

\section{Blood cell aggregation studies}

Tissue engineering scaffolds, wound dressings and skin substitutes are in direct 
Table 1. Microbial barrier property ( \%) of PCL/ZnO nanocomposite membranes with reference to positive control (standard wound coverage material "Cipla FirstAid")

\begin{tabular}{|c|c|}
\hline Samples & Microbial barrier property \\
\hline Neat PCL membrane & $95 \pm 3$ \\
\hline PCL/ZnO-1 & $96 \pm 1$ \\
\hline PCL/ZnO-2 & $95 \pm 2$ \\
\hline PCL/ZnO-4 & $97 \pm 1$ \\
\hline PCL/ZnO-6 & $95 \pm 2$ \\
\hline
\end{tabular}

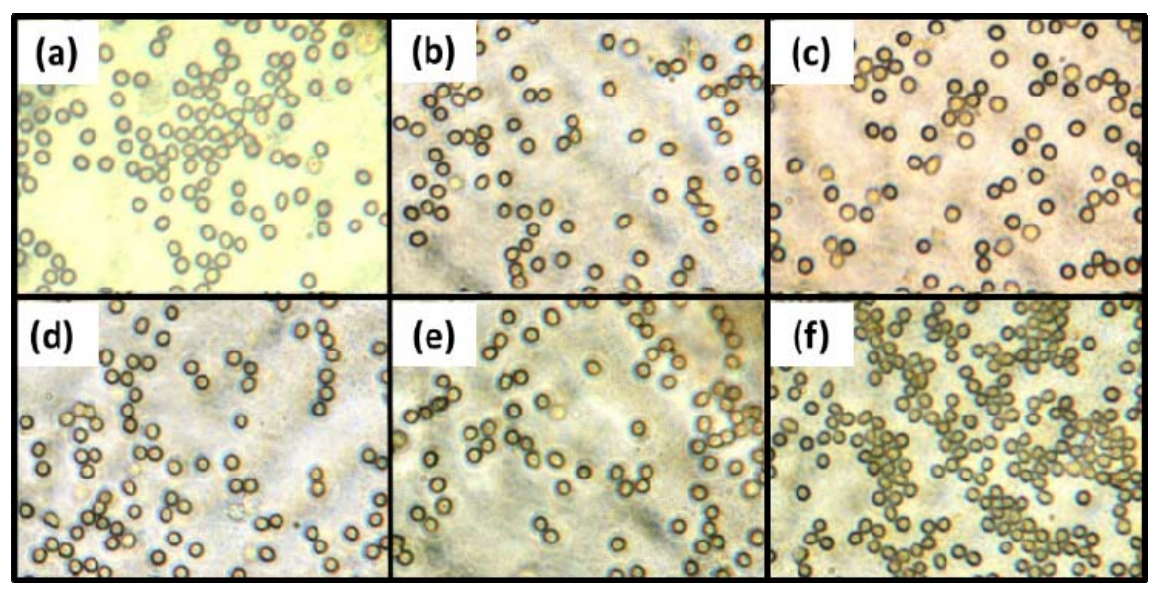

Fig. 2. Aggregation of RBC due to neat PCL membrane (a), $1 \% \mathrm{w} / \mathrm{w}$ (b), $2 \% \mathrm{w} / \mathrm{w}$ (c) and $6 \% \mathrm{w} / \mathrm{w}$ (d) $\mathrm{ZnO}$ nanoparticles containing PCL membranes. (e) and (f) represents RBC aggregation in negative and positive controls respectively

contact with the blood at the application site. A material that causes aggregation of blood cells, especially RBC and WBC cannot be used for such blood contact applications. Since the PCL/ $\mathrm{ZnO}$ nanocomposite membranes are intended to be used as skin substitute materials, it is important to study the aggregation of blood cells on interaction with them. The aggregations of the blood cells on interaction with materials released from $\mathrm{PCL} / \mathrm{ZnO}$ nanocomposite membranes are shown in Fig. 2 and Fig. 3, for RBC and WBC respectively. It confirmed that there was no aggregation of blood cells on incubation with any of the studied samples. Polyethyeleneimine (PEI) which was used as positive control showed aggregation whereas saline which was used as negative control did not induce any aggregation.
The obtained results were comparable with that of normal saline.

Thus, the electrospun $\mathrm{PCL} / \mathrm{ZnO}$ nanocomposite membranes can be used for blood contact applications like skin substitutes.

\section{Platelet activation}

Hemostasis is a process which causes bleeding to stop. It is the first stage of wound healing. Platelet activation is considered as the initial step of blood coagulation. Within seconds of a blood vessel's epithelial wall being disrupted, platelets begin to aggregate together and starts to spread (Boon, 1993). Many instances like use of vascular constructs, cardiac implants, the materials used should not elicit platelet aggregation. However, it is advisable 


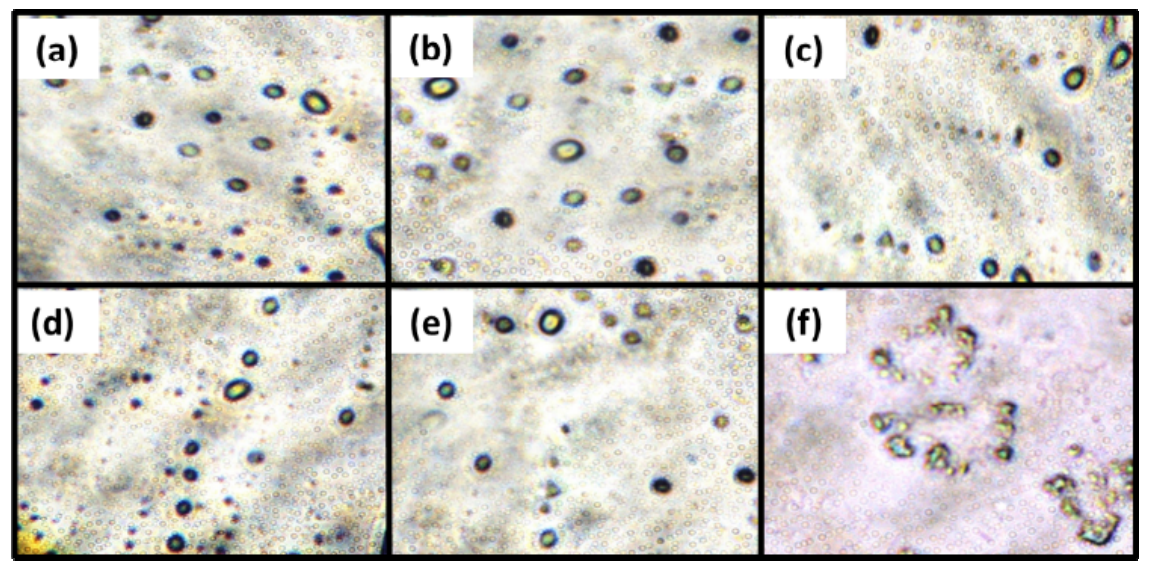

Fig. 3. Aggregation of WBC due to neat PCL membrane (a), $1 \% \mathrm{w} / \mathrm{w}$ (b), $2 \% \mathrm{w} / \mathrm{w}$ (c) and $6 \% \mathrm{w} / \mathrm{w}$ (d) $\mathrm{ZnO}$ nanoparticles containing PCL membranes. (e) and (f) represents WBC aggregation in negative and positive controls respectively

to have hemostatic property for materials like wound dressings and skin substitutes to initiate coagulation to avoid excessive bleeding (Ulsh et al., 2013).

From Fig. 4, it is evident that platelets treated with $\mathrm{PCL} / \mathrm{ZnO}$ nanocomposite membranes have shown platelet activation. Neat PCL membranes and PCL/ZnO-0.5 membranes did not show any sign of platelet activation. PCL membranes with $\mathrm{ZnO}$ nanoparticle concentrations of $1 \% \mathrm{w} / \mathrm{w}$ and above showed platelet activation. In such cases, platelets aggregated together as clumps and spread in a circular manner. Platelet plug formation is an important event in hemostasis, platelets stick together to form a temporary seal to cover the break in the vessel wall. They allow for the creation of the "platelet plug" that forms almost soon after a blood vessel has been ruptured.

Reactive oxygen species are known to induce platelet activation and subsequent aggregation (Forde et al., 1997). The reactive oxygen species generated by $\mathrm{ZnO}$ nanoparticles might have enhanced the platelet aggregation. Thus, PCL/ $\mathrm{ZnO}$ nanocomposite membranes were able to induce coagulation by platelet activation and can act as effective hemostatic wound coverage materials.

\section{Hemolysis test}

Another important property to be tested to demonstrate the blood compatibility of biomedical materials is the hemolysis due to the material. It is well-known that red blood cells lyses when they come in contact with certain materials including water. Hemocompatibilty has been calculated with respect to a negative control (Normal saline-assumed as $0 \%$ hemolytic) and a positive control (Double distilled waterassumed as $100 \%$ hemolytic). According to ASTM standards, $1 \%$ is the acceptable limit of hemolysis (ASTM Standard, F756-08). The hemolysis test results of the PCL membranes and $\mathrm{PCL} / \mathrm{ZnO}$ nanocomposite membranes are shown in Table 2. All the tested samples have shown less than $1 \%$ hemolysis which indicates good hemocompatibility for all the membranes irrespective of $\mathrm{ZnO}$ nanoparticle concentration. Thus, these hemocompatible scaffolds can be used as skin substitutes which are in contact with blood.

\section{Conclusion}

The electrospun PCL/ZnO nanocomposite membranes have been fabricated by electrospinning technique and evaluated for the microbial barrier 


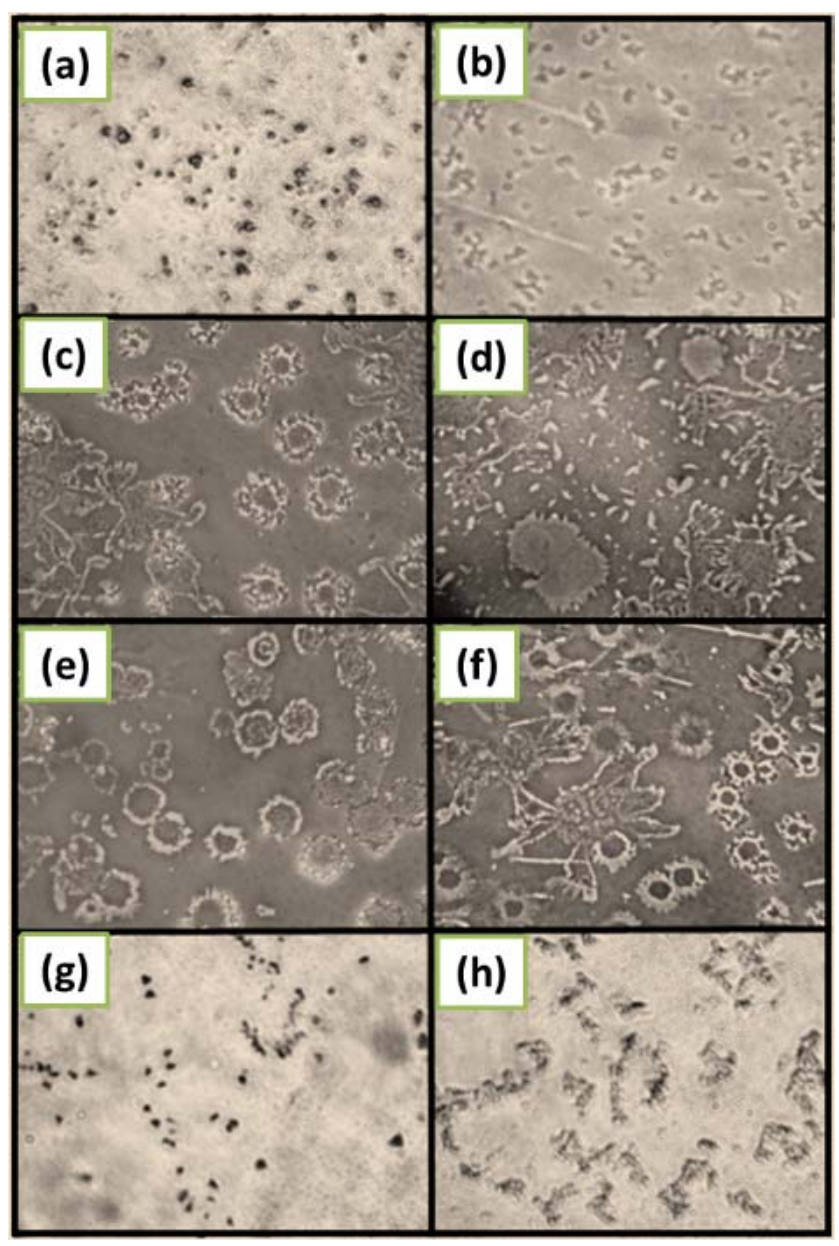

Fig. 4. Platelet activation and spreading; platelets incubated with neat PCL membrane (a), $0.5 \%$ w/w (b), $1 \% \mathrm{w} / \mathrm{w}(\mathrm{c}), 2 \% \mathrm{w} / \mathrm{w}(\mathrm{d}), 4 \% \mathrm{w} / \mathrm{w}$ (e) and $6 \% \mathrm{w} / \mathrm{w}$ (f) ZnO nanoparticles containing PCL membranes. (g) and (h) represents platelets incubated with negative and positive controls respectively

Table 2. Percentage of hemolysis due to the effect of PCL and PCL/ZnO nanocomposite membranes

\begin{tabular}{|c|c|}
\hline Sample & Hemolysis ( \%) \\
\hline Neat PCL & $0.2 \pm 0.02$ \\
\hline PCL/ZnO-0.5 & $0.2 \pm 0.05$ \\
\hline PCL/ZnO-1 & $0.2 \pm 0.08$ \\
\hline PCL/ZnO-2 & $0.3 \pm 0.02$ \\
\hline PCL/ZnO-4 & $0.2 \pm 0.06$ \\
\hline PCL/ZnO-6 & $0.3 \pm 0.04$ \\
\hline Negative control & 0 \\
\hline Positive control & 100 \\
\hline
\end{tabular}


property and blood compatibility. PCL/ZnO nanocomposite membranes have shown good microbial barrier property which suggest the ability of the fabricated material to prevent the bacterial invasion at the implantation site. All the fabricated membranes have possessed excellent microbial barrier property, irrespective of the $\mathrm{ZnO}$ nanoparticle content. Though there was aggregation of platelets in the presence of PCL/ $\mathrm{ZnO}$ nanocomposite scaffolds containing more than $1 \% \mathrm{w} / \mathrm{w} \mathrm{ZnO}$ nanoparticles, both blood cell aggregation studies and hemolysis tests have demonstrated the blood compatibility of the PCL/ $\mathrm{ZnO}$ nanocomposite membranes.

\section{Acknowledgements}

RA thanks Science Engineering Research Board (SERB), New Delhi, India for National Postdoctoral Fellowship (NPDF) (Reference Number PDF/2016/000499).

\section{References}

Allen C., Han J., Yu Y., Maysinger D., Eisenberg A. (2000) Polycaprolactone/poly (ethylene oxide) copolymer micelles as a delivery vehicle for dihydrotestosterone. J Control Release, 63(3): 275-286

Augustine R., Dan P., Sosnik A., Kalarikkal N., Tran N., Vincent B., Thomas S., Menu P., Rouxel D. (2017a) Electrospun poly (vinylidene fluoride-trifluoroethylene)/zinc oxide nanocomposite tissue engineering scaffolds with enhanced cell adhesion and blood vessel formation. Nano Res. Doi:10.1007/s12274-017-1549-8

Augustine R., Dominic E.A., Reju I., Kaimal B., Kalarikkal N., Thomas S. (2014a) Investigation on angiogenesis and its mechanism using zinc oxide nanoparticles-loaded electrospun tissue engineering scaffolds. RSC Adv, 4(93): 51528-51536

Augustine R., Dominic E.A., Reju I., Kaimal B., Kalarikkal N., Thomas S. (2014b) Electrospun polycaprolactone membranes incorporated with $\mathrm{ZnO}$ nanoparticles as skin substitutes with enhanced fibroblast proliferation and wound healing. RSC Adv, 4(48): 24777-24785

Augustine R., Kalarikkal N., Thomas S. (2015) An in vitro method for the determination of microbial barrier property (MBP) of porous polymeric membranes for skin substitute and wound dressing applications. Tissue Eng Regen Med, 12(1): 12 - 19

Augustine R., Kalarikkal N., Thomas S. (2016a) Effect of $\mathrm{ZnO}$ nanoparticles on the in vitro degradation of electrospun polycaprolactone membranes in simulated body fluid. Int J Polym Mat Polym Biomat, 65(1): 28-37

Augustine R., Kalarikkal N., Thomas S. (2016b) Electrospun PCL membranes incorporated with biosynthesized silver nanoparticles as antibacterial wound dressings. Appl Nanoscie, 6(3): 337-344

Augustine R., Malik H.N., Singhal D.K., Mukherjee A., Malakar D., Kalarikkal N., Thomas S. (2014c) Electrospun polycaprolactone/ZnO nanocomposite membranes as biomaterials with antibacterial and cell adhesion properties. J Polym Res, 21(3): 1-17

Augustine R., Mathew A.P., Sosnik A. (2017b) Metal oxide nanoparticles as versatile therapeutic agents modulating cell signaling pathways: Linking nanotechnology with molecular medicine. Appl Mat Today, 7: 91-103

Augustine R., Nethi S.K., Kalarikkal N., Thomas S., Patra C. (2017c) Electrospun polycaprolactone (PCL) scaffolds embedded with europium hydroxide nanorods (EHNs) with enhanced vascularization and cell proliferation for tissue engineering applications. J Mater Chem B. Doi: 10.1039/C7TB00518K

Boon G.D. (1993) An overview of hemostasis. Toxicol Pathol, 21(2): 170-179 
Eldsäter C., Erlandsson B., Renstad R., Albertsson A.C., Karlsson S. (2000) The biodegradation of amorphous and crystalline regions in film-blown poly (€-caprolactone). Polymer, 41(4): 1297-1304

Forde R.C., Fitzgerald D.J. (1997) Reactive oxygen species and platelet activation in reperfusion injury. Circulation, 95(4): 787-789

Hutmacher D.W., Schantz T., Zein I., Ng K.W., Teoh S.H., Tan K.C. (2001) Mechanical properties and cell cultural response of polycaprolactone scaffolds designed and fabricated via fused deposition modeling. J Biomed Mat Res, 55(2): 203-216

Nandagopal S., Augustine R., George S.C., Jayachandran V.P., Kalarikkal N., Thomas S. (2016) Gentamicin loaded electrospun poly ( $\varepsilon$-caprolactone)/TiO2 nanocomposite membranes with antibacterial property against Methicillin resistant Staphylococus aureus (MRSA). Polym Plast Technol Eng, 55(17): 1785-1796

Recek N., Resnik M., Motaln H., Lah-Turnšek T., Augustine R., Kalarikkal N., Thomas S., Mozetič M. (2016) Cell adhesion on polycaprolactone modified by plasma treatment. Int J Polym Sci, 2016: Article ID 7354396, 9 pages. Doi: 10.1155/2016/7354396

Smith L.A., Ma P.X. (2004) Nano-fibrous scaffolds for tissue engineering. Colloids Surf B: Biointerf, 39(3): 125-131

Ulsh G., Le D., Moy J., McDermott M., Collins G. (2013) ChitO2-Clot: a novel hemostatic and oxygen releasing biomaterial for traumatic injuries. Bioeng Conf (NEBEC), 39th Annual Northeast. P. 100-101

Wang G., Chen X.Y., Huang R., Zhang L. (2002) Nano- $\mathrm{CaCO}_{3} /$ polypropylene composites made with ultra-high-speed mixer. J Mat Scie Lett, 21(13): 985-986

Zahedi P., Rezaeian I., Ranaei-Siadat S.O., Jafari S.H., Supaphol P. (2010) A review on wound dressings with an emphasis on electrospun nanofibrous polymeric bandages. Polym Adv Technol, 21(2): 77-95

Zhong Z., Sun X.S. (2001) Properties of soy protein isolate/polycaprolactone blends compatibilized by methylene diphenyl diisocyanate. Polymer, 42(16): 6961-6969 